\title{
Considerations regarding the risks of obesity and physical inactivity
}

\section{DOI: http://doi.org/10.26758/8.1.9}

\section{Constanța Urzeală}

National University of Physical Education and Sports from Bucharest, Romania

Address correspondence to: Constanța Urzeală, Sports and Motor Performance Department, UNEFS, 140 Constantin Noica Street, 6th District, Bucharest, Romania, Ph.: +40/21 3164107, Fax: +40/21 3120400; E-mail: constanta.urzeala@unefs.ro

\begin{abstract}
This paper aims to emphasize the risks of obesity and physical inactivity, knowing that an unhealthy lifestyle based on sedentariness, a chaotic rhythm of work programmes and sleeping hours, and inappropriate food ingestion in terms of quality and regularity of meals is a major factor in disturbing the individual's well-being. Evidence shows that physical activity can be used as a preventive measure or a secondary care standard for chronic health issues related to obesity, such as cardiovascular disease, type 2 diabetes mellitus, colon cancer and stroke. Recent studies are focused on the efficiency of different obesity management strategies in order to avoid obesity-related comorbidities. Physical activity fosters the mental and functional balance of the individual, ensures good body weight control, improves and contributes to maintaining the health status, satisfies the need for movement, responds to the need for group affiliation and social interaction, and provides contexts for personal communication. Despite the people's awareness of the statistics, their involvement in physical activity is low. Physical exercise programmes should be approached as medical prescriptions for an optimal state of health, being a medicine with no negative effect if properly applied, but with many health benefits. Changes in a person's lifestyle related to physical exercise, diet and harmful leisure result from the congruence of several political, economic, ideological and educational factors.
\end{abstract}

Keywords: health, physical inactivity, well-being.

\section{Introduction}

An unhealthy lifestyle based on physical inactivity, a chaotic rhythm of work programmes and sleeping hours, inappropriate food ingestion in terms of quality and regularity of meals is a major factor in disturbing the individual's well-being. Moreover, vicious habits like smoking, alcohol, drugs, gambling cause a decrease in the quality of life. In this context, all people's actions are reflected in their health status, which makes it imperative to promote a balanced way of living since early ages.

In 2016, the World Health Organization (WHO) has highlighted once again that obesity is an alarmingly increasing disease. According to statistics, more than 1.9 billion adults (39\%) were overweight, and of these, over 650 million (13\%) were obese worldwide (***WHO, 2017).

In 2014, across all EU Member States, $51.6 \%$ of the adult population was estimated to be overweight and obese. In Romania, the proportion of women considered to be overweight was 
almost $50 \%$, and of these, $9.7 \%$ were obese, while for the male adult population, more than $60 \%$ was overweight and $9.1 \%$ was obese (***Eurostat Statistics, 2017).

The classification for overweight and obese adults is made by calculating their Body Mass Index (BMI), knowing that an index $\geq 25$ corresponds to overweight, while a BMI $\geq 30$ shows obesity (Katzmarzyk et al., 2000). The most common cause of obesity and overweight is an energy imbalance between ingested calories and consumed calories, but other genetic and environmental causes can be investigated. Also, recent studies are focused on the efficiency of different obesity management strategies designed not to regain weight after losing it (Rogge \& Gautam, 2017).

Obesity is associated with comorbidities such as cardiovascular disease, type 2 diabetes mellitus, musculoskeletal disorders and certain cancers (Fruh, 2017).

Various epidemiologic studies have revealed that physical activity is inversely linked to cardiovascular morbidity and mortality (Koolhaas, 2016). Recent meta-analyses support the benefits of regular physical activity on the coronary heart disease. Moderate-to-high levels of physical activity can reduce the risk of this heart disease by up to $27 \%$ (Sofi, 2008).

Obese people, who have a genetic predisposition for type 2 diabetes and are physically inactive, can develop this metabolic disease as they grow older (Nielsson, 2017). The progression from prediabetes to type 2 diabetes depends on the obesity management (*** American Diabetes Association, 2017), including the involvement of patients in physical exercise programmes. In the United States, evidence suggests that 1 in 3 adults have prediabetes, more than 1 in every 10 adults being diagnosed with diabetes (Santos-Longhurst, 2017). In addition, diabetes is considered to become the $7^{\text {th }}$ leading cause of death at a global level in 2030 (*** WHO, 2017). From another perspective, people diagnosed with type 2 diabetes can balance their blood glucose levels and not develop type 1 diabetes if they follow the medical prescription, the diet and change their lifestyle into a physically active one (Rothberg, 2014).

Hidayat et al. (2017) demonstrate that body fatness at an early age may affect colon cancer risk later in life. The authors support the idea of preventing overweight and obesity in young people to avoid the early onset of colon cancer caused by excess body fatness.

It is known that the regular practice of physical activity reduces the risk of obesity by lowering fat mass and positively influencing lean mass in older adults (Bann et al., 2014). Instead, specialists identify a potentially vicious cycle including weight gain, obesity, and complications associated with a sedentary lifestyle (Golubic et al., 2013).

\section{Issues addressed}

Evidence shows that physical activity can be used as a preventive measure or a secondary care standard for chronic health issues related to obesity, such as cardiovascular disease (Daren, 2013; Go, 2013; Pagac, 2008), type 2 diabetes mellitus (Colberg, 2010; Dharmastuti et al., 2017; ***American Diabetes Association, 2017), colon cancer and stroke (Brown, 2017; Adamsen, 2017). Moreover, specialists have demonstrated that physical inactivity also increases the risk of osteoporosis (Dolan, 2017; Watson, 2017; Mack, 2017). Lack of physical activity is an important modifiable risk factor for bone mineral density. Time spent in sedentary behavior or in nonexercising seated and reclining postures has recently emerged as a new public health risk, independent of the amount of time someone spends being active (Chastin et al., 2017).

Psychologically, obesity can be related to low self-esteem, lack of self-confidence, embarrassment in various social contexts etc. Thus, discrimination, labeling, rejection, and self- 
victimization can exert a strong emotional pressure on an overweight or obese person (Milici, 2015, p.64).

Nowadays, social relationships are influenced by the somatic appearance of the individual. Being "too fat" attracts negative consequences and leads to serious emotional scars. Nuttall (2015, p.117) states that "societal discrimination limits career choices, and indeed many career paths are closed to those considered to be too fat. Also, societal stigma often impairs a person's ability to express his/her intellectual and other talents; that is, they become underachievers".

Sociologists highlight the fact that some individuals choose to practice physical activities for their somatic appearance, for having a body that matches the aesthetic social rigors, in order to align with the lifestyle of those in the group to which they belong, to keep up with what is fashionable or what the society claims to be beneficial to its members. This interest in one's appearance may lead to the choice of less beneficial physical activities, in sanogenetic terms. We refer here to situations where gym or fitness centers are attended only to meet certain social needs, without understanding the principles of exercising, the advantages of systematically practicing physical exercise and adopting a healthy lifestyle. Few people are aware that they engage in movement for their own development and the health-related benefits, thus choosing physical activities with low efficiency for them. We can also add here situations where individuals use drastic measures to lose weight in order to match social norms in the shortest possible time, adopting unhealthy diets and physical exercise programmes that are inappropriate for their bodies.

With age, people's interest in physical activity changes, the main reason being their desire to stay young as long as possible, with no health problems. Constrained by his/her own fears, the individual may adhere to physical activity, but without necessarily seeking its recreational, playful and energy balancing sides. The functional limitations that accompany degenerative processes will influence the engagement in physical activities and their choice. These issues may exert a strong psychological pressure on the person, requiring intense processes of accepting one's own physical capabilities and their downward curve after adulthood.

In recent studies, physical exercise is addressed as a bio-medicine associated with optimal health (Orgeret, 2008, p.52). In Canada and the United States, a new concept has been developed, namely "Exercise is Medicine", according to which physical activity has a major integrative role in the prevention and treatment of diseases, being necessary to include it as part of all healthcare (***Exercise is Medicine, 2017).

The challenge of living with a chronic disease makes people with health-related problems a disadvantaged population, their treatment exerting a high pressure on their lifestyles. Any chronic disease that affects the health status will keep the individual away from physical activity. There may be cases where only certain exercises are allowed or situations where effort is completely forbidden. Physical inactivity and health problems may increase the risks to which the individual is exposed due to possible complications. In terms of social integration, there are situations where individuals suffering from chronic diseases are often marginalized, excluded, isolated, avoided.

Physical activity fosters the mental and functional balance of the individual, ensures good body weight control, improves and contributes to maintaining the health status, satisfies the need for movement, responds to the need for group affiliation and social interaction, provides contexts for personal communication and expression. Overall, physical activity combats the stress of everyday life and increases the quality of life for those who practice it (Dragnea \& Teodorescu, 2002, p.42). The benefits of the exercise are directly related to the individual's movement capabilities, which in turn will condition the performance of daily activities, whether they are professional, administrative and/or domestic. The development of fitness components and the formation of motor skills have 
positive effects on the functional, physiological and psychological levels, acting on the individual's state of health. The indissoluble connection between the motor, functional, biological, psychological and social sides of the individual will condition the optimal development of his/her body and its evolution. For elderly people, the objectives of practicing motor activities are related to slowing down degenerative processes, increasing socialization for those retired, combating anxiety and the feeling of worthlessness or depression. Table 1 shows a synthesis of the functional adaptations and prophylactic effects induced by the regular practice of physical exercise (Dumitru, 1997, p.17).

Table 1. Functional adaptations and prophylactic effects due to physical activity

\begin{tabular}{|c|c|c|}
\hline $\begin{array}{l}\text { System or } \\
\text { function }\end{array}$ & Functional adaptations & Prophylactic effects on: \\
\hline Cardiovascular & $\begin{array}{l}\text { Increased amount of blood pumped by the heart } \\
\text { Increased amount of blood existing in the vessels } \\
\text { Blood becomes more fluid and flows more easily } \\
\text { through arteries and veins }\end{array}$ & $\begin{array}{l}\text { Arteriosclerosis } \\
\text { Ischemic heart disease } \\
\text { Hypertension }\end{array}$ \\
\hline Pulmonary & Increased pulmonary ventilation & $\begin{array}{l}\text { Chronic pulmonary } \\
\text { disease }\end{array}$ \\
\hline $\begin{array}{l}\text { Skeletal } \\
\text { muscles }\end{array}$ & $\begin{array}{l}\text { Increased muscle mass and muscle tone } \\
\text { Increased muscle strength and local muscle } \\
\text { endurance }\end{array}$ & $\begin{array}{l}\text { Lumbar disease } \\
\text { Fractures that frequently } \\
\text { occur in the elderly }\end{array}$ \\
\hline Adipose tissue & $\begin{array}{l}\text { Decreased fat mass and adipose tissue around } \\
\text { the organs }\end{array}$ & $\begin{array}{l}\text { Obesity } \\
\text { Metabolic disease }\end{array}$ \\
\hline $\begin{array}{l}\text { Carbohydrate } \\
\text { metabolism }\end{array}$ & $\begin{array}{l}\text { Increased ability of the muscle to extract blood } \\
\text { glucose }\end{array}$ & Diabetes \\
\hline Fat metabolism & $\begin{array}{l}\text { Increased ability to use lipids as an energy } \\
\text { substrate }\end{array}$ & Arteriosclerosis \\
\hline Immunity & $\begin{array}{l}\text { Increased ability of the immune system to } \\
\text { respond to microbial aggression and resist illness }\end{array}$ & $\begin{array}{l}\text { Infection, virus disease, } \\
\text { flu }\end{array}$ \\
\hline Digestion & Improved intestinal transit & Colon disease \\
\hline $\begin{array}{l}\text { Nervous } \\
\text { system }\end{array}$ & Increased coordination and balance & $\begin{array}{l}\text { Fractures caused by } \\
\text { domestic accidents }\end{array}$ \\
\hline $\begin{array}{l}\text { Cognitive } \\
\text { function }\end{array}$ & Increased reaction speed & Injuries \\
\hline $\begin{array}{l}\text { Psychosocial } \\
\text { behavior }\end{array}$ & $\begin{array}{l}\text { Improved self-image, professional efficacy, } \\
\text { harmonious family behavior, zest for life }\end{array}$ & $\begin{array}{l}\text { Depression, anxiety, } \\
\text { emotional disorders, } \\
\text { social integration } \\
\text { difficulties }\end{array}$ \\
\hline
\end{tabular}

\section{Discussions}

Despite the people's awareness of the statistics and the dynamic evolution of the fitness industry, the individuals' involvement in physical activity does not record the same ascending rate, most of them being inactive from this point of view (Janssen, 2017; Thanamee, 2017). Golubic et al. (2014) conducted a research on British people aged 60-64, demonstrating that their physical activity involvement was generally low. Milosević et al. (2009) studied the physical inactivity level in 
Croatia, emphasizing that, in Zagreb, 39.6\% men and $43.6 \%$ women had a sedentary lifestyle. In Romania, it is noticed that people are physically inactive from early ages, and the habit of being sedentary tends to extend throughout their lifetime (Albu et al., 2016; Neagu, 2016). Studies reveal that most adults often spend their leisure time watching TV, rented movies, listening to music (Rada, 2017), while children are attracted to electronic devices and playing computer games.

It is difficult to attract to physical exercise programmes the adults who have not had contact with sport but understand the necessity of practicing it and want to change their lifestyle into an active, dynamic, healthy one. Knowing that the habit of practicing physical activity is formed at young ages, physical exercise should be an integral part of the educational act so as to stimulate the desire for movement and maintain the individual's motivation for a regular exercise regime. Socially speaking, the education level is given by the family members. Building an active lifestyle depends on the education level of parents, who in turn have to be engaged in physical exercise programmes both for their own well-being and to be a model for their children. Romanian specialists demonstrate that there are significant differences in the way leisure time is spent based on environment, gender, education level and age (Rada, 2015). The adult's openness to the physical activity valences will be directly reflected in the child's level of involvement in physical exercise programmes. Thus, in the long run, the risk of illness and health disorders decreases as a result of fighting sedentary lifestyle.

The socio-economic conditioning, that influences people's participation in physical activities (Teodorescu \& Popescu, 2016), is equally important. Considering the large number of children who do not attend primary education, it is easy to understand that pupils from socially disadvantaged environments do not even participate in the compulsory physical education and sports (PES) lessons to which they would have free access. The access to sports halls, sports clubs or wellness centers for children is often hampered by poor transport and infrastructure. With the exception of large cities, where the children's clubs for physical activities as leisure have constantly grown in recent years, in many other localities, the only opportunity to do sports is within the PES lesson or the professional sports clubs. Although, at the European level, the emphasis is put on physical activity as a pillar of optimal health, in Romania, performance sport is brought to the forefront. Even if statistics indicate a major drop in the number of children choosing performance sports activities, specialized sections within the school sports clubs do not organize leisure activities and do not include groups of children willing to practice sports for all. Therefore, if children are not talented for performance sport and/or do not wish to engage in this form of physical exercise, they have few opportunities to engage in leisure physical activities.

In addition, the lack of a sports culture and of healthy attitude of the society toward continuing education (Bota, 2006, p.123) is emphasized by the poor participation in the current physical education curriculum and the time budget management so that to provide available resources for extracurricular physical activities. The importance given to the PES subject, as compared to other study subjects focused on developing the child's cognitive processes, is reflected in the large number of children who are medically exempt from physical exercise, not always for justified reasons, but also in the small number of those practicing extracurricular sports activities. The busy schedules of both the pupils and their parents are other factors that may lead to the child's physical inactivity. Doing homework, taking private lessons in various school subjects that mainly stimulate the child's cognitive development and the time spent in traffic to go to school and come back home are the most common reasons given by parents to justify the reduced participation of their children in physical activities. From the adult's perspective, the alert pace of daily life, the unbalanced distribution of leisure and work time, the double workload of women often generated by the low economic level and unequal gender division of household chores are strong arguments that 
cause physical inactivity and implicitly the exposure of their health to the risks of obesity and sedentariness.

\section{Conclusions}

The WHO statistics are alarming, indicating numerous cases of illness caused by physical inactivity in people of any age. Regardless of the country, both physicians and specialists in physical education and sport recommend the practice of physical exercise to counteract the effects of a sedentary lifestyle, fight obesity and mitigate the effects of mental and social pressures due to daily stress in order to replace harmful, self-destructive habits in the individuals' lifestyles.

Physical activities emerge as a powerful link between the real significance of the individual's health status and his/her optimal functioning, between the integrity of the body and the expression of its maximum potential, between existing and living.

Physical exercise programmes should be approached as medical prescriptions for an optimal state of health, being a medicine with no negative effect if properly applied, but with many sanogenetic benefits.

Changes in a person's lifestyle related to physical exercise, diet and harmful leisure result from the congruence of several political, economic, ideological and educational factors. In this context, the risk of chronic diseases and mental disorders can be diminished by conjugating the powerful actions undertaken by decision-makers at the level of national and European systems.

\section{References}

1. Adamsen, L., Andersen, C., Lillelund, C., Bloomquist, K., Møller, T., 2017. Rethinking exercise identity: a qualitative study of physically inactive cancer patients' transforming process while undergoing chemotherapy. British Medical Journal Open, 23, 7(8):e016689, doi: 10.1136/bmjopen-2017-016689.

2. Albu, A., Onose, I., Negrea, M., Cracana, I. and Hodorca, R.M., 2016. Correlation between physical diagnostic and exercise in a group of teens from Garabet Ibrăileanu High School of Iași. The European Proceedings of Social \& Behavioural Sciences, vol XI, pp.273-279.

3. Bann, D., Kuh, D., Wills, A.K., Adams, J., Brage, S., Cooper, R., 2014. Physical activity across adulthood in relation to fat and lean body mass in early old age: findings from the Medical Research Council National Survey of Health and Development, 1946-2010. American Journal of Epidemiology, 179, pp.1197-1207. doi: 10.1093/aje/kwu033.

4. Bota, A., 2006. Exerciții fizice pentru viața activă. București: Cartea Universitară.

5. Brown, J.C., Zemel, B.S., Troxel, A.B., Rickels, M.R., Damjanov, N., Ky, B., Rhim, A.D., Rustgi, A.K., Courneya, K.S., Schmitz, K.H., 2017. Dose-response effects of aerobic exercise on body composition among colon cancer survivors: a randomized controlled trial. British Journal of Cancer Online Publication, 21, doi: 10.1038/bjc.2017.339.

6. Chastin, S.F., Mandrichenko, O., Helbostadt, J.L., Skelton, D.A., 2014. Associations between objectively-measured sedentary behaviour and physical activity with bone mineral density in adults and older adults, the NHANES study. Bone, 64, pp.254-262, doi: 10.1016/j.bone.2014.04.009.

7. Colberg, S.R., Sigal, R.J., Fernhall, B., Regensteiner, J.G., Blissmer, B.J., Rubin, R.R.,ChasanTaber, L., Ann, L., Albright, A.L., Braun, B., 2010. Exercise and Type 2 Diabetes. The 
American College of Sports Medicine and the American Diabetes Association: joint position statement. Diabetes Care, 33(12), pp.147-167, doi: 10.2337/dc10-9990.

8. Darden, D., Richardson, C., Jackson, E.A., 2013. Physical activity and exercise for secondary prevention among patients with cardiovascular disease. Current Cardiovascular Risk Report, 7(6), pp.411-416, doi: 10.1007/s12170-013-0354-5.

9. Dharmastuti, D.P., Agni, A.N., Widyaputri, F., Pawiroranu, S., Sofro, Z.M., Wardhana, F.S., Haryanto, S., Widayanti, T.W., Kotha, S., Gupta, P., Sasongko, M.B., 2018. Associations of physical activity and sedentary behaviour with vision-threatening diabetic retinopathy in Indonesian population with type 2 diabetes mellitus: Jogjakarta eye diabetic study in the community (joged.com). Ophthalmic Epidemiology, 25(2), pp.113-119. doi: 10.1080/09286586.2017.1367410. Epub 2017 Oct 12.

10. Dolan, E., Swinton, P.A., Sale, C., Healy, A., O'Reilly, J., 2017. Influence of adipose tissue mass on bone mass in an overweight or obese population: systematic review and meta-analysis. Nutrition Reviews, 75(10), pp.858-870. doi: 10.1093/nutrit/nux046.

11. Dragnea, A. and Teodorescu, S., 2002. Teoria sportului. București: FEST.

12. Dumitru, Gh., 1997. Sănătate prin sport pe înțelesul fiecăruia. București: Federația Română Sportul pentru toți.

13. Fruh, S.M., 2017. Obesity: Risk factors, complications, and strategies for sustainable long-term weight management. Journal of American Association Nurse Practitioners, 29(S1), pp.3-14. doi: 10.1002/2327-6924.12510.

14. Go, A.S., Mozaffarian, D., Roger, V.L. et al., 2013. Heart disease and stroke statistics--2013 update: a report from the American Heart Association. Circulation, 127(1):e6-e245. Available at: https://www.ncbi.nlm.nih.gov/pmc/articles/PMC5408511/ [Accessed 24 October 2017]

15. Golubic, R., Ekelund, U., Wijndaele, K., Luben, R., Khaw, K.T., Wareham, N.J., Brage, S., 2013. Rate of weight gain predicts change in physical activity levels: a longitudinal analysis of the EPIC-Norfolk cohort. International Journal of Obesity, 37(3), pp.404-409. doi: 10.1038/ijo.2012.58.

16. Golubic, R., Martin, K.R., Ekelund, U., Hardy, R., Kuh, D., Wareham, N., Cooper, R., Brage, S., 2014. Levels of physical activity among a nationally representative sample of people in early old age: results of objective and self-reported assessments. International Journal of Behavioral Nutrition and Physical Activity, 3(11), p.58. doi: 10.1186/1479-5868-11-58. Available at: https://www.ncbi.nlm.nih.gov/pmc/articles/PMC4038114/ [Accessed 24 October 2017]

17. Hidayat, K., Yang, C.M., Shi, B.M., 2017. Body Fatness at an Early Age and Risk of Colorectal Cancer. International Journal of Cancer, doi: 10.1002/ijc.31100, Available at: http://onlinelibrary.wiley.com/doi/10.1002/ijc.31100/abstract;jsessionid=FC9437DA624429FF0 80F989C185BE55C.f04t03 [Accessed 24 October 2017].

18. Janssen, E., Ruiter, R.A.C., Waters, E.A., 2017. Combining risk communication strategies to simultaneously convey the risks of four diseases associated with physical inactivity to sociodemographically diverse populations. Journal of Behavioral Medicine, 5, pp. 1-15. doi: 10.1007/s10865-017-9894-3.

19. Katzmarzyk, P., Pérusse, L., Rao, D.C., Bouchard, C., 2000. Familial Risk of Overweight and Obesity in the Canadian Population using the WHO/NIH Criteria. Obesity Research \& Clinical Practice, 8(2), pp.194-197. 
20. Koolhaas, C.M., Dhana, K., Golubic, R., Schoufour, J.D., Hofman, A., van Rooij, F.J.A., Franco, O.H., 2016. Physical Activity Types and Coronary Heart Disease Risk in Middle-Aged and Elderly Persons: The Rotterdam Study. American Journal of Epidemiology, 183(8), pp.729738, https://doi.org/10.1093/aje/kwv244.

21. Mack, D.E., Wilson, P.M., Santos, E., Brooks, K., 2017. Standards of reporting: the use of CONSORT PRO and CERT in individuals living with osteoporosis. Osteoporosis International, 10, pp.1-19, doi: 10.1007/s00198-017-4249-z.

22. Milici, N., 2015. Sindromul metabolic şi obezitatea. Perspective antropologice (Metabolic syndrome and the obesity. Anthropological perspectives), București: Editura Academiei Române.

23. Milosević, M., Golubić, R., Mustajbegović, J., Jelinić, J.D., Holcer J.N., Kern, J., 2009. Regional pattern of physical inactivity in Croatia. Collegium Antropologicum, 33(1), pp.35-38.

24. Neagu, A., 2016. Les pressions liées à l'apparence et la gestion du poids dans un échantillon des adolescents de Bucarest (Appearance-related pressures and weight management in an adolescent sample from Bucharest). In: III Colloque International Francophone "Mondialisation des comportements alimentaires et facteurs de risques pour l'obésité et le diabète”, Sofia: Simel Press Edt. pp.81-92.

25. Nilsson, E., Ling, C., 2017. DNA methylation links genetics, fetal environment, and an unhealthy lifestyle to the development of type 2 diabetes. Clinical Epigenetics Online, 9, p.105, doi: $\quad$ 10.1186/s13148-017-0399-2.

Available at: https://clinicalepigeneticsjournal.biomedcentral.com/articles/10.1186/s13148-017-0399-2, [Accessed 24 October 2017]

26. Nuttall, F.Q., 2015. Body Mass Index: Obesity, BMI, and Health: A Critical Review. Nutrition Today, 50 (3), pp.117-128, doi: 10.1097/NT.0000000000000092.

27. Orgeret, G., 2008. Le sport est un médicament bio. Trouver le sport adapté à son état de santé. Paris: Ed. J. Lyon, pp.9-62.

28. Rada, C., 2015. How is leisure time spent in Romania, factors involved, Revista de Psihologie, 61(2), pp.85-96.

29. Rada, C., 2017. Impact of some demographic parameters on leisure time and body weight. Anthropological Researches and Studies, 7, pp.111-121.

30. Rogge, M.M., Gautam, B., 2017. Biology of obesity and weight regain: Implications for clinical practice. Journal of the American Association Nurse Practioners, 29(S1), pp.15-29. doi: 10.1002/2327-6924.12504.

31. Rothberg, A.E., McEwen, L.N., Kraftson, A.T., Fowler, C.E., Herman, W.H., 2014. Very-lowenergy diet for type 2 diabetes: an underutilized therapy?, Journal of Diabetes Complications, 28, pp.506-510.

32. Santos-Longhurst, A., 2017. Type 2 Diabetes Statistics and Facts. Health line. Available at: https://www.healthline.com/health/type-2-diabetes/statistics [Accessed 16 October 2017].

33. Sofi, F., Capalbo, A., Cesari, F. et al. 2008. Physical activity during leisure time and primary prevention of coronary heart disease: an updated meta-analysis of cohort studies. European Journal of Cardiovascular Prevention and Rehabilitation, 153, pp.247-257.

34. Teodorescu, S., Popescu, L., 2016. Considerations about equal opportunities in sport. Discobolul-Physical Education, Sport and Kinetotherapy Journal, Vol. XII no.2(44), pp.13-16.

35. Thanamee, S., Pinyopornpanish, K., Wattanapisit, A., Suerungruang, S., Thaikla, K., Jiraporncharoen, W., Angkurawaranon, C., 2017. A population-based survey on physicalinactivity and leisure time physical activity among adults in Chiang Mai, Thailand, 
2014. Archive of Public Health, 75(41), doi: 10.1186/s13690-017-0210-z. Available at: https://archpublichealth.biomedcentral.com/articles/10.1186/s13690-017-0210-z [Accessed 24 October 2017].

36. Watson, S.L., Weeks, B.K., Weis, L.J., Harding, A.T., Horan, S.A., Beck, B.R., 2018. HighIntensity Resistance and Impact Training Improves Bone Mineral Density and Physical Function in Postmenopausal Women with Osteopenia and Osteoporosis: The LIFTMOR Randomized Controlled Trial. Journal of Bone and Mineral Resources, pp.211-220, doi: 10.1002/jbmr.3284. Epub 2017 Oct 4. Available at: http://onlinelibrary.wiley.com/wol1/doi/10.1002/jbmr.3284/full [Accessed 24 October 2017].

37. *** American Diabetes Association, 2017. Physical Activity. What can physical activity do for me? Available at: http://www.diabetes.org/are-you-at-risk/lower-your-risk/activity.html [Accessed 16 October 2017].

38. *** American Diabetes Association.2017. Obesity Management for the Treatment of Type 2 Diabetes. Diabetes Care, 40(S1), pp.57-63. https://doi.org/10.2337/dc17-S010

39. ***European Commission. 2017. Eurostat Statistics Explained. Overweight and obesity - BMI statistics. Available at: http://ec.europa.eu/eurostat/statisticsexplained/index.php/Overweight_and_obesity___BMI_statistics [Accessed 16 October 2017].

40. *** Exercise is Medicine. 2017. Available at: http://exerciseismedicine.org/. [Accessed 24 October 2017].

41. *** Physical Activity Guidelines Advisory Committee. 2008, Physical activity guidelines advisory committee report. Washington DC: US Department of Health and Human Services Available at:https://health.gov/paguidelines/report/pdf/CommitteeReport.pdf [Accessed 24 October 2017].

42. *** World Health Organization (WHO), 2017. Diabetes. Fact sheet. Available at: http://www.who.int/mediacentre/factsheets/fs312/en/ [Accessed 16 October 2017].

43. *** World Health Organization (WHO), 2017. Obesity and overweight. Fact sheet. Available at: http://www.who.int/mediacentre/factsheets/fs311/en/ [Accessed 16 October 2017]. 